\title{
The Endocrine Hypothalamus: An Historical Review
}

\author{
T. F. L.ÉVÊQUE
}

The history of the hypothalamus and neuroendocrinology is so intimately related to the development of our ideas on the disease known as diabetes insipidus, that any discussion of the one must include a discussion of the other. Many authors have compared the history of diabetes insipidus to a comedy of errors. Indeed, the whole problem seems to have fared rather badly from the very beginning when Magnus and Schafer (1901), and Schafer and Herring (1905) demonstrated that extracts of the posterior lobe of the pituitary body had a diuretic effect rather than the antidiuretic effect as we know it today. Furthermore, from a histological point of view, Herring (1908) and later Cushing (1933) were of the opinion that the cellular constituents of the posterior lobe were incapable of secreting the active factors attributed to that lobe and that consequently a search had to be made elsewhere for the secretory cells. Herring (1913) visualized the secreting cells as coming from the pars intermedia and migrating into the pars nervosa where they degenerated and released the "hormones". Cushing (1933) fully subscribed to this and in 1933 stated rather emphatically that "it is scarcely conceivable that the neural core of the lobe is capable independently of elaborating a hormone."

From 1906 to 1913 various investigators undertook the study of the effects of posterior lobe extracts in a variety of animals. Although most had to admit that their findings were

\footnotetext{
From the Depiltment of Anatomy. Ficulty of Medicine. University of Sherbrooke. Sherbrooke. Quebec, Cimadia.

Reprint Address: Dr. 'T. F. Lévêque, Depatment af Anatomy. Faculty of Medicine. University of Sherbrooke. Sherbrooke. Quebec. Canadia.
}

not constant, the results tended to show that the posterior lobe of the pituitary body contained a substance capable of increasing urine flow. Houghton and Merrill (1908) stated that the increased flow lasted nineteen minutes in the dog. In 1909, Halliburton, Candler, and Sikes (1909) reported the observation of increased urine output in cats. This was confirmed a year later by Ott and Scott (1910). Falta, Newburgh, and Nobel (1911) repeatedly observed a diuresis following an intravenous injection of pituitrin. De Cyon (1910) obtained similar results by feeding dry pituitary preparations. Finally, Herring (1913) stated that the diuretic effect of the posterior lobe extracts could be shown in all species of animals and that anterior and intermediate lobe extracts did not seem to possess a diuretic activity.

In all fairness to the above investigators, it must be said that they undoubtedly observed increased urine flow in a great number of cases even though, as we stated above, many of them had had to admit that the results were far from constant. Nonetheless, as Motzfeldt (1917) points out, all the early investigators made use of Schafer's recording method, a method which was open to criticism. The recording technique employed by Schafer consisted of inserting a cannula directly into the bladder and registering the number of drops excreted over a period of time. Under such conditions, an increase in the number of drops obtained could have been due to the tonic action of the bladder which seemed to be a constant effect following the injection of pituitary extracts. Furthermore, the observations were made only over very short periods of time and on animals which had not been previously hydrated. It is now known that previous hydration gives much more constant results, and it is also known that the activity of pituitary extracts should be measured over a period of hours rather than minutes. Finally, all of the early observations seem to have been made on anesthetized animals without taking into consideration the possible effects of the anesthesia on the mechanism concerned. The confusion, then, came about as a result of the inadequacy of the method employed rather than from the lack of close observation.

In 1913, von den Velden (1913) and Farini (1913) independently demonstrated that the administration of posterior lobe extracts led to water retention in the intact human subject. These observations were soon confirmed by other investigators Frey and Kumpiess (1913), von Konschegg and Schuster (1915). The idea that diabetes insipidus was due to a deficiency rather than an oversecretion of posterior lobe hormone gained further acceptance when Goldzieher (1913) and Simmonds (1914) advocated it on the basis of autopsy findings.

The demonstration that lesions of the hypophysis were responsible for the polyuria seen in diabetes insipidus, led many investigators to attempt to study the question by the production of experimental lesions in laboratory animals. The problem was immediately thrown into a further state of confusion when Camus and Roussy (1913b) presented data which indicated that basal lesions of the hypothalamus which were presumably independent of lesions of the 
hypophysis could also cause an increase in urine output and a polydipsia. Moreover, they reported that total hypophysectomy did not result in increased urine flow. Subsequent to the publication of these findings, two seemingly unreconcilable hypotheses were advanced as explanations for the etiology of diabetes insipidus. One of these hypotheses was based on the premise that the seat of humoral control of water balance lay exclusively in the hypothalamus, whereas the other hypothesis was based on the premise that humoral control of urine excretion was exclusively a function of the posterior lobe of the hypophysis.

The voluminous literature on the arguments advanced by the "hypothalamists" and "hypophysists" was extensively reviewed and criticized by Fisher, Ingram and Ranson (1938). I will confine myself to a presentation of some of the broader aspects of each of the two hypotheses.

Camus, Roussy, and their coworkers Camus and Gournay (1923), (1924a), (1924b), (1925); Camus, Gournay and Fiterre (1923); Camus and Roussy (1913a), (1913b), (1914a), (1914b), (1914c), (1920); Camus, Roussy, and LeGrand (1923), made a thorough study of the role which the hypothalamus plays in the control of water balance in the dog. Their findings seemed to bear out three main points: 1) that total hypophysectomy would not result in permanent diabetes insipidus, 2) that lesions of the hypothalamus would result in increased urine output and 3) that a polyuria could be elicited by hypothalamic puncture in totally hypophysectomized animals. These points were thought to have been well confirmed by Cushing (1913), Leschke (1919), Warner (1931), Mahoney and Sheehan (1936), Camus and co-workers Camus and Gournay, (1923), (1924a), (1924b), (1925); Camus, Gournay and Fiterre, (1923); Camus and Roussy, (1913a), (1913b), (1914a), (1914b), (1914c), (1920); Camus, Roussy and LeGrand, (1923), Bailey and Bremer (1921), Hanchette (1922) and Reichert and Dandy (1936), to name but a few. In their criticisms, Fisher et al, brought out the following points: first, in most instances the early investigators were able to elicit only a transient polyuria. Secondly, in cases where histological findings were reported, there seemed to be some doubt as to the completeness of the hypophysectomy. Finally, most of the investigators reported that their lesions resulted in atrophy of the neural lobe. From this, Fisher et al (1938) concluded that the posterior lobe could not be eliminated from a possible participation in the mechanism of water balance.

The experimental evidence did not seem to support the hypophyseal theory to the same extent as the clinical evidence. As a consequence, the arguments presented by the "Hypophysists" were based on the rather tenuous contention that since the bulk of the pharmacodynamic factor concerned with water balance can be extracted from the posterior lobe of the pituitary, it must be secreted at this site. Verney (1925), (1926), (1929), (1936) showed that the perfused isolated kidney excreted large quantities of a hypotonic urine. When pituitrin was added to the perfusate, however, the urine flow diminished and the specific gravity of the urine was close to "normal." $\mathrm{He}$ elaborated on this by including several tissues into the circuit, i.e. head, spleen, liver, etc. It was found that when the perfusate was passed through the head, the results were similar to those which were observed after the inclusion of pituitrin in the perfusate. He concluded from this that since the results were similar to those obtained by the injection of pituitrin in the intact animal, the pituitary body must be responsible for the proper maintenance of the active water reabsorption by the kidney. None of the "hypophysists" mentioned the hypothalamus except as a source of nerve fibers for the innervation of the posterior lobe.

From their thorough review of the experimental and clinical evidence and from their own extensive observations in the cat and monkey, Fisher et al (1938) favored a composite of the views advanced by the "hypothalamists" and by the "hypophysists." According to them, "the hypothalamus regulated the secretory activity of the neural division of the hypophysis through the supraoptico-hypophyseal system." In order to accept this concept, however, one would have to assume that the posterior lobe of the pituitary body contains secretory elements. The only elements which could perform this function are the pituicytes and this was shown not to be the case Lévêque and Scharrer (1953). Furthermore, one would also have to show that the pituicytes are actually innervated by fibers from the supraoptico-hypophyseal tract. Gagel and Mahoney (1936), Mahoney and Sheehan (1936), and Keller (1942) showed, however, that diabetes insipidus does not necessarily result from interruption of the supraoptic tract. According to these authors, only lesions in the immediate vicinity of the supraoptic nucleus cause permanent diuresis; section of the pituitary stalk halfway between the hypothalamus and pituitary was not followed by more than a temporary disturbance of the excretion of water. Another aspect concerns the observation of Rasmussen (1938) who pointed out that there are many more fibers in the supraoptico-hypophyseal tract than would be necessary to innervate the cells of the neurohypophysis. Furthermore, only some of the investigators were able to demonstrate actual contact between nerve fibers and pituicytes Brooks and Gersh (1938), Tavares de Sousa (1943), Romieu and Stahl (1950). Others state that the pituicytes do not receive nerve terminals from the supraoptico-hypophyseal tract Hair (1938), Rasmussen (1938), Vazquez-Lopez (1942), Green (1948). Actually, Vazquez-Lopez (1942), Hagen (1949-50), and Stotler (1962), showed that many fibers end at blood vessels in the posterior pituitary. These fibers do not innervate the vessels, but store neurosecretory material which contains the posterior lobe hormones Bodian (1951), Hild (1952). Consequently, there was little if any basis for the assumption that the pituicytes were stimulated by nervous impulses originating in the supraoptic nucleus and that such stimulation caused the 
pituicytes to produce the posterior lobe hormones.

A different avenue of approach was opened by the observation of nerve cells in the hypothalamus which exhibited the cytological characteristics of secretory cells. Gaupp and Scharrer (1935) suggested that these cells possess the endocrine function attributed to the neural lobe. However, due to technical difficulties, it was impossible to substantiate the theory at that time. It was not until Bargmann and his coworkers in the late 1940's and early 1950's Bargmann (1949a), (1949b), (1950), Bargmann and Jacob (1952), Bargmann and Hild (1949), Bargmann, Hild, Ortmann and Schiebler (1950), Ortmann (1950) made use of the chrome alum haematoxylin phloxin stain developed by Gomori for the study of the islet cells of the pancreas that the phenomenon of neurosecretion could be definitely linked to the posterior lobe and its hormones. With this technique secretory granules could be demonstrated in certain cells of the supraoptic and paraventricular nuclei, and these granules could also be seen in the axons of the supraoptichypophyseal tract as well as at the terminals of the axons in the neurohypophysis. It has since been demonstrated that the stainability is due not so much to the presence of the hormones but of a carrier "protein" Hild and Zetler (1952b), (1953a).

As we now know, the utilization of the chrome alum haematoxylin phloxin stain and that of other selective stains, which were subsequently employed, led to the demonstration that physiological events which caused the release of the posterior lobe hormones also caused the simultaneous decrease in stainable substance. Furthermore, interruption of the hypophyseal stalk caused an accumulation of neurosecretory material at the proximal end of the cut stalk establishing the close relationship between cellular activity in the secretory nuclei, principally the magnocellular portion of the supraoptic and paraventricular nuclei, and hormone release. This secretory activity has since been confirmed many times at the ultramicroscopic level.

From the accumulated data it was possible to formulate a hypothesis which would explain the apparent confusion in the development of our understanding of the aetiology of diabetes insipidus.

According to the new concept which was termed the "Neurosecretory" concept, the supraoptic and paraventricular nerve cells synthesise the posterior lobe hormones which then pass along the fibers of the supraopticohypophyseal tract to gain the neurohypophysis. Then the hormones are stored in the nerve terminals from which they are released directly into the blood vessels whenever the physiological conditions demand it. Sharrer and Scharrer (1963), Stutinsky (1970).

The acceptance of the role of the hypothalamus in endocrine mechanisms opened up a broad new area of research. Indeed in the last decade especially, we have witnessed the demonstration of an ever broadening implication of the hypothalamus as a final common pathway in the modulation of most if not all hormonal activity. For that reason, and because it is the site of synthesis of the posterior lobe hormones, and is also known to elaborate a great variety of other humoral substances, such as the "releasing" and "inhibitory" factors, no matter how else one might classify the hypothalamus it has now gained the status of an "endocrine organ."

\section{REFERENCES}

BAILEY, P., and BREMER, F. (1921) Experimental diabetes insipidus. Archives of Internal Medicine, 28, 773-803.

BARGMANN, W. (1949a) Uber die neurosekretorishes Verknupfung von Hypothalamus und Neurohypophyse. Zeitschrift für Zellforschung und Mikroskopiche Anatomie, 34, 610654.

BARGMANN, W. (1949b) Uber die neurosekretorische Verknupfung von Hypothalamus und Hypophyse. Klinische Wochenschrift, 27, 617-662.
BARGMANN, W. (1950) Die elektive Darstellung einer marklosen diencophalen Bahu. Microskopie, 5, 289 . 292.

BARGMANN, W. and JACOB, E. (1952) Uber Neurosekretion in Zwischenhirn der Vogel. Zeitschrift für Zellforschung und Mikroskopiche Anatomie, 36, 556-562.

BARGMANN, $W$. and HILD, W. (1949) Uber die Morphologie der neurosekretorischen Verknupfung von Hypothalamus und Neurohypophyse. Acta Anatomica, 8, 264-280.

BARGMANN, W., HILD, W., ORTMANN, R., and SCHIEBLER, T. H. (1950) Morphologische und experimentelle Untersuchungen uber das hypothalamisch-hypophysare System. Acta Neurovegetativa, 1, 233-275.

BODIAN, D. (1951) Nerve endings, neurosecretory substance, and lobular organization of the neurohypophysis. Johns Hopkins Hospital Bulletin, 89, 354-376.

BROOKS, G. M., and GERSH, I. (1938) Pericellular nerve terminations in the pars nervosa and pars distalis of the rat's pituitary. Anatomical Record, Suppl. 70, 10-11.

CAMUS, J., et GOURNAY, J. J. (1923) La polyurie tubérienne après énervation des reins. Comptes Rendus des Seances de la Societe de Biologie et de Ses Filiales, 88, 694-696.

CAMUS, J., et GOURNAY, J. J. (1924a) Action diurétique des bases puriques. Comptes Rendus des Seances de la Societe de Biologie et de Ses Filiales, 90, 335-336.

CAMUS, J., et GOURNAY, J. J. (1924b) Recherches sur la diabète insipide. Comptes Rendus des Seances de la Societe de Biologie et de Ses Filiales, 91, 1137-1139.

CAMUS, J., et GOURNAY, J. J. (1925) Recherches sur la diabète insipide et la diurese. Comptes Rendus Hebdomandaires des Seances de L'Académie des Seances; D:Sciences Naturelles, 180, 172.

CAMUS, J., GOURNAY, J. J., et FITERRE, H. (1923) Sur le mécanisme du diabète insipide. Comptes Rendus Hebdomadaires des Seances de L'Académie des Seances: D:Sciences Naturelles, 177, 289.

CAMUS, J., et ROUSSY, G. (1913a) Hypophysectomie et polyurie expérimentale. Comptes Rendus des Seances de la Societe de Biologie et de Ses Filiales, 75, 483-486. 
CAMUS, J., et ROUSSY, G. (1913b) Polyurie expérimentale par lésions de la base du cerveau. La polyurie dite hypophysaire. Comptes Rendus des Seances de la Societe de Biologie et de Ses Filiales, 75, 628-633.

CAMUS, J., et ROUSSY, G. (1914a) Polyurie et polydipsie par lésions nerveuses expérimentales. Régulation de la teneur en eau de l'organisme. Comptes Rendus des Seances de la Societe de Biologie et de Ses Filiales, $76,121-124$.

CAMUS, J., et ROUSSY, G. (1914b) Polyurie par lésion de la région optopédonculaire de la base du cerveau, mécanisme régulateur de la teneur en eau de l'organisme. Comptes Rendus des Seances de la Societe de Biologie et de Ses Filiales, 76, 773-778.

CAMUS, J., et ROUSSY, G. (1914c) Localisation anatomique â la base du cerveau des lésions que provoque la polyurie chez le chien. Comptes Rendus des Seances de la Societe de Biologie et de Ses Filiales, 76, 877-880.

CAMUS, J., and ROUSSY, G. (1920) Experimental researches on the pituitary body. Endocrinology, 4, 507-522.

CAMUS, J., ROUSSY, G., et LeGRAND, A. (1923) Sur le mécanisme du diabète insipide. Comptes Rendus Hebdomadaires des Seances De L'Acadamie des Seances; D:Sciences Naturelles, 177, 289.

CUSHING, H. (1913) Concerning diabetes insipidus and the polyurias of hypophyseal origin. Boston Medical and Surgical Journal, 168, 901-910.

CUSHING, H. (1933) Posterior pituitary activity from an anatomical standpoint. American Journal of Pathology, 9, 539-549.

DeCYON, E. (1910) Die Gefassdrussen als regulatorische Shutzorgane des Zentralnervensystems, Berlin (quoted from Motzfeldt).

FALTA, W., NEWBURGH, L. H., and NOBEL, E. (1911) Uber die Wechselwirkung der Drusen mit innerer Sekretien. Zeitschrift für Klinische Medizin, 72, 97.

FARINI, A. (1913) Diabete insipide ed opoterapia ipofisaria. Gazzetta degli Ospedali e delle cliniche, 34, 1135.

FISHER, C., INGRAM, W. R., and RANSON, S. W. Diabetes insipidus and the neuro-hormonal control of water balance; a contribution to the structure and function of the hypothalamico-hypophyseal system. Edwards Brothers, Inc.: Ann Arbor, Michigan.
FREY, W., and KUMPIESS, K. (1913) Die Beeinflussung der Harnausscheidung beim Menschen durch Pituglandol. Zeitschrift für die Gesamte Experimentelle Medizin einschliesslich Experimentelle Chirurgie, 2, 380396.

GAGEL, O., and MAHONEY, W. (1936) Zur Frage des Zwischenhirnhypophysensystems. Zeitschrift für Neurologie, 156, 594-613.

GAUPP, R., and SCHARRER, E. (1935) Die Zwischenhirnsekretion bei mensch und Tier. Zeitschrift für Neurologi und Psychiatrie, 153, 327-355.

GOLDZIEHER, M. (1913) Uber Sekretionbefunde bei Diabetes Insipidus. Verhandlungen der Deutschen Gesellschaft für Pathologie, 16, 281-287.

GREEN, J. D. (1948) The histology of the hypophyseal stalk and median eminence in man with special reference to blood vessels, nerve fibers, and a peculiar neurovascular zone in this region. Anatomical Record, 100, 273-297.

HAGEN, E. (1949-50) Neurohistolgische Untersuchungen an der menschlichen Hypophyse. Zeitschrift für Anatomie und Entwicklungsgeschichte, 114, 640-679.

HAIR, G. W. (1938) The nerve supply of the hypophysis of the cat. Anatomical Record, 71, 141-160.

HALLIBURTON, W. D., CANDLER, J. P., and SIKES, A. W. (1909) The human pituitary body. Quarterly Journal of Experimental Physiology, 2, 229-242.

HANCHETT, M. (1922) Experimental polyuria. American Journal of the Medical Sciences, 163, 685-697.

HERRING, P. T. (1908) The histological appearance of the mammalian pituitary body. Quarterly Journal of Experimental Physiology, 1, 121-159.

HERRING, P. T. (1913) Further observations upon the comparative anatomy and physiology of the pituitary body. Quarterly Journal of Experimental Physiology, 6, 73-108.

HILD, W. (1952) Uber Neurosekretion in Zwischenhirn des Menschen. Zeitschrift für Zellforschung und Mikroskopische Anatomie, 37, 301-316.

HILD, W., and ZETLER, G. (1952b) Neurosekretion und Hormonvorkommen in Zwischenhirn des Menschen. Klinische Wochenschrift, 30, 433-439.

HILD, W., and ZETLER, G. (1953a) Uber die Funktion des Neurosekrets im Zwischenhirnhypophysensystem als Trager Substanz für Vasopressin, Oxytocin and Adiuretin. Zeitschrift fuer die Gesamte Experimentelle Medizin, 120, 236-243.

HOUGHTON, E. M., and MERRILL, C. H. (1908) The diuretic action of adrenalin and the active principle of the pituitary gland. Jounal of the American Medical Association, 51, 1849-1854.

KELLER, A. D. (1942) Elimination of the pars nervosa without eliciting diabetes insipidus. Endocrinology, 30, 408-422.

VON KONSCHEGG, A., and SCHUSTER, E. (1915) Uber die Beeinflussung der Diurese bei Hypophysenextrakte. Deutsche Medizinische Wochenschrift, 41, 1091-1095.

LESCHKE, E. (1919) Beitrage sur klinischen Pathologie des Zwischenhirns. Zeitschrift für Klinische Medizin, 87, 201.

LÉVÊQUE, T. F., and SCHARRER, E. (1953) Pituicytes and the origin of the antidiuretic hormone. Endocrinology, 52, 436-447.

MAGNUS, R., and SCHAFER, E. A. (1901) The action of pituitary extracts upon the kidney. Journal of Physiology, 27, 9-10.

MAHONEY, W., and SHEEHAN, D. (1936) The pituitary hypothalamic mechanism; experimental occlusion of the pituitary stalk. Brain, 59, 61-75.

MOTZFELDT, K. (1917) Experimental studies on the relation of the pituitary body of renal function. Journal of Experimental Medicine, 25, 153-188.

ORTMANN, R. (1950) Morphologischexperimentelle Untersuchungen uber das diencephal-hypophysare System in Verhaltnis zum Wasserhaushalt. Klinische Wochenschrift, 28, 449.

OTT, I., and SCOTT, J. C. (1910) Action of glandular extracts upon the secretion of urine. American Medicine, 15, 79-83.

RASMUSSEN, A. T. (1938) Innervation of the hypophysis. Endocrinology, 23, 263-278.

REICHERT, F. L., and DANDY, W. E. (1936) Polyuria and polydipsia (diabetes insipidus) and glycosuria resulting from animal experiments on the hypophysis and its environs. Bulletin of the Johns Hopkins Hospital, 58, 418-427.

DeROBERTIS, E., and PRIMAVESI, L. (1942) Cytology of neurohypophysis of the rat after water privation and 
injection of pitressin. Revista de la Sociedad Argentina de Biologia, 18, 363-365.

ROMIEU, M., and STAHL, A. (1950) Comptes Rendus de L'Association des Anatomistes 37. Reunion (Louvain), p. 418 .

SCHAFER, E. A., and HERRING, P. T. (1905) The action of pituitary extracts on the kidney. Proceedings of the Royal Society of London: Series B: Biological Sciences, 77, 571-572.

SCHARRER, E., and SCHARRER, B. (1963) Neuroendocrinology. Columbia University Press.

SIMMONDS, M. (1914) Uber sekundare Geschwulste des Hirnanhangs und ihre Beziehungen zum Diabetes Insipidus. Munchener Medizinische Wochenschrift, 61, 180.

STARLING, E. H., and VERNEY. E. B. (1925) The secretion of urine as studied on the isolated kidney. Proceedings of the Royal Society of London: Series B: Biological Sciences, 97, 321-363.

STOTLER, A. (1962) The relationship of the terminals of the hypothalamicohypophyseal tract to the morphology of the pars nervosa of the hypophysis of the cat. Anatomical Record, 114, 275.

STUTINSKY, F. S. (1970) In The Hypothalamus. Edited by L. Martini, M. Motta, and 'F. Fraschini. Academic Press: New York and London.

TAVARES DE SOUSA, A. (1943) These de Coimbra (quoted from Romieu and Stahl, 1950).

VAZQUEZ-LOPEZ, E. (1942) Structure of the neurohypophysis with special reference to nerve endings. Brain, 65, 1-33.

VON DEN VELDEN, R. (1913) Die Hierenwirkung von Hypophyse- sextrakten beim Menschen. Berliner Klinische Wochenschrift, 50, 20832088.

VERNEY, E. B. (1926) The secretion of pituitrin in mammals as shown by perfusion of the isolated kidney in the dog. Proceedings of the Royal Society of London: Series B; Biological Sciences, 99, 487-517.

VERNEY, E. B. (1929) Goulstonian lectures on polyuria. I. Polyuria associated with pituitary dysfunction. Lancet, 1, 539-546.

VERNEY, E. B. (1936) Die Wasserausscheidung der Saugetierniere und ihre physiologische Regulation. Naunyn-Schmiedeberg's Archiv für Experimentelle Pathologie und Pharmakologie, 181, 24-37.

WARNER, F. J. (1931) Histopathology of experimental diabetes insipidus. Journal of Nervous and Mental Disease, 73, 375-383. 